\title{
LA LECTURA HELENÍSTICA DEL CANTAR DE LOS CANTARES *
}

\author{
N. FERNÁNDEZ MARCOS \\ CSIC. Madrid
}

La lectura de la traducción griega del Cantar como poesía lírica amorosa requiere una breve incursión por la poesía de amor helenística. $\mathrm{Y}$ ante todo es preciso evocar a Safo, poetisa de Lesbos del siglo VI antes de la Era común. En efecto, así como sin Homero no se explica la ciencia de los filólogos alejandrinos, sin Safo es impensable la poesía de amor helenística. Ella es la gran maestra de los poetas líricos; en ella se inspiran Teócrito y Antípatro de Sidón; la imitan Meleagro y Filodemo de Gadara; la imita, parafrasea y traduce Catulo!

Existen por lo demás patrones de expresión amorosa que se encuentran tanto en la lírica egipcia como en los himnos sumerios a Inanna, en las cantigas de amor del Medioevo o en los idilios de Teócrito ${ }^{2}$. Antes de entrar en la traducción griega del Cantar voy a fijarme en algunos de estos temas de la tradición grecorromana.

El amor ausente. Entre los fragmentos anónimos atribuidos a Safo se encuentra este breve poema en el que difícilmente se puede expresar tanto con tan pocas palabras:

* Trabajo presentado en el Curso de verano «Razón de amor. Cantar de los Cantares de Salomón", organizado por la Fundación General de la Universidad Complutense en San Lorenzo de El Escorial (8-12 de julio de 1996).

${ }^{1}$ Sobre el influjo de los poetas helenísticos en la poesía romana del siglo I a. E. c., especialmente en Catulo, cf. G. O. Hutchinson, Hellenistic Poetry, Oxford 1988, págs. 296-325; en pág. 297 leemos: «Plainly Catullus and his friends were greatly influenced by Hellenistic models".

${ }^{2}$ Incluso W. G. Seiple, después de consignar una serie de paralelos entre el original hebreo del Cantar y los idilios de Teócrito, reconoce que sería aventurado concluir que el autor del Cantar tomó préstamos de este poeta griego o de la poesía griega en general: «In the nature of the case, the themes of the Song of Songs and the idyls of Theocritus are somewhat similar, and it is only natural that a similarity of theme should occasion a choice of similar language. And after all, the language of love is the language of the heart the world over»; cf. W. G. SEIPLE, «Theocritean Parallels to the Song of Songs», AJSL 19 (1903) 108-115, 115. 
Se han ocultado la luna

y las Pléyades,

es media noche,

pasó la hora,

y yo durmiendo sola ${ }^{3}$.

El amor sueña imposibles. Las Anacreónticas del Codex Palatinus son una colección apócrifa que se ampara en el nombre del poeta jonio de la isla de Teos de mediados del siglo VI a. E. c., pero, en realidad, se trata de un género literario que ni es de Anacreonte ni, en principio, de fecha muy antigua. Todo apunta en ellas a una datación incluso postalejandrina ${ }^{4}$. Entre estas composiciones dedicadas al tema del amor y el vino se encuentra la siguiente canción a una joven. Su autor evoca las figuras mitológicas de Procne y Filomela, que perseguidas por Tereo invocan a los dioses y éstos las salvan transformándolas en golondrina y ruiseñor respectivamente.

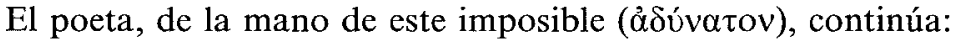

Quién fuera espejo, para que de continuo me miraras, o túnica me hiciera para que día a día me llevases.

En agua mudarme quiero para lavar tu piel; perfume, mujer, volverme, para ungirte; ceñidor para tus senos, para tu cuello perla y hasta de sandalia hiciera, con tal de que con tus plantas me pisaras ${ }^{5}$.

Juegos de amor. En los poemas de Catulo (Verona 84-Roma 54 a. E. c.) late la pasión amorosa por Lesbia y la admiración por Safo. Lejos queda el erotismo como artificio literario de algunos poetas alejandrinos o la atmósfera de convencionalismo de muchas anacreónticas y de los epigramas de la escuela siro-fenicia. He aquí el siguiente poema, dedicado a Lesbia, que evoca la exclamación de los primeros versos del Cantar:

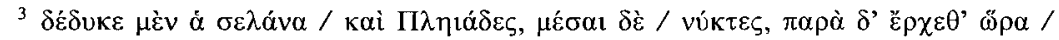

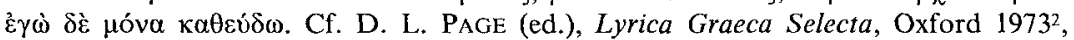
pág. $251, \mathrm{n}^{2} 468$. Las traducciones de estos poemas, mientras no se diga lo contrario, son mías.

${ }^{4}$ M. Brioso Sánchez (ed.), Anacreónticas, Madrid 1981, págs. XXVII y IX-XIX.

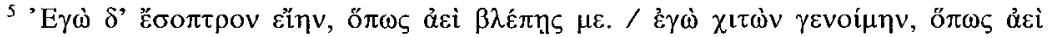

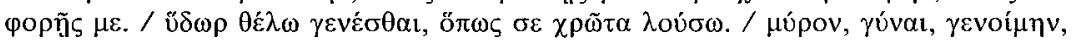

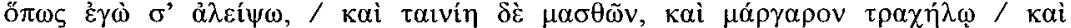

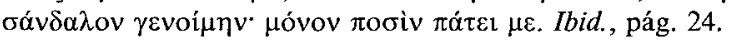


Vivamos, Lesbia mía, amémonos y no nos importen un as todas las habladurías de los severos ancianos. Los soles pueden declinar y reaparecer. Nosotros, apenas haya declinado nuestra breve llama, tendremos que dormir una sola noche perdurable. Dame mil besos, luego ciento, luego otros mil, luego cien más, luego otros mil todavía, luego ciento. Después, cuando hayamos sumado muchos miles, embrollaremos la cuenta para no saberla o para que ningún envidioso pueda aojarnos cuando sepa que fueron tantos nuestros besos ${ }^{6}$.

Deslumbramiento, fascinación y ternura. El poema siguiente de Catulo es, en sus tres primeras estrofas, paráfrasis o traducción libre de una conocida oda de Safo y suele fecharse en los primeros tiempos de sus relaciones con Lesbia. Dice así:

Me parece que es igual a un dios, me parece, si no es impiedad, que sobrepasa los dioses aquel que, sentado ante ti, sin cesar te contempla y te oye, sonreir dulcemente, dicha que arrebata a mi pobre alma todos los sentidos; pues apenas te he visto, Lesbia, se me apaga «la voz en la boca», se me paraliza la lengua, un fuego sutil corre por mis miembros, me zumban con un sonido interior los oídos, y una doble noche se extiende sobre mis ojos ${ }^{7}$.

\footnotetext{
${ }^{6}$ Vivamus, mea Lesbia, atque amemus, / rumoresque senum seueriorum / omnes unius aestimemus assis. / Soles occidere et redire possunt; / nobis cum semel occidit breuis lux, / nox est perpetua una dormienda. / Da mihi basia mille, deinde centum, / dein mille altera, dein secunda centum, / deinde usque altera mille, deinde centum. $/$ Dein, cum millia multa fecerimus, / conturbabimus illa, ne sciamus, / aut ne quis malus inuidere possit, / cum tantum sciat esse basiorum. Cf. M. DolÇ (trad.), G. Valerio Catulo. Poesías, Barcelona 1963, pág. 6. La traducción castellana de los poemas de Catulo es de M. Dolç. Ver también A.-J. Festugrère, La vie spirituelle en Grèce à l'époque hellénistique ou les besoins de l'esprit dans un monde raffiné, París 1977, págs. 191-220.

7 Ille mi par esse deo uidetur, / ille, si fas est, superare diuos, / qui sedens aduersus identidem te / spectat et audit / dulce ridentem, misero quod omnis / eripit sensus mihi; nam simul te, / Lesbia, aspexi, nihil est super mi / "vocis in ore", / lingua sed torpet, tenuis sub artus / flamma demanat, sonitu suopte / tintinant aures, gemina teguntur / lumina nocte. Cf. M. DoLC, $O p$. cit., pág. 43. Por su interés para la comparación transcribo a continuación las dos primeras estrofas de la oda de Safo que sirvió de modelo a Catulo, y que se encuentra en la edición de D. L. PAGE,

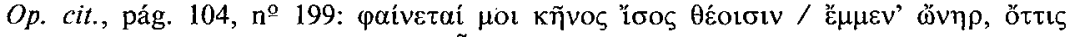

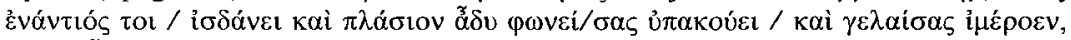

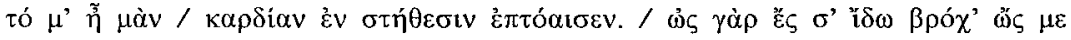

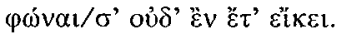


Éste es, en un apunte rápido, el marco de poesía erótica helenística en el que nace la traducción griega del Cantar. La cultura griega mediterránea impregna los países limítrofes desde las conquistas de Alejandro. Alejandría, Siria o Rodas, por citar las tres escuelas helenísticas más importantes de poesía lírica, apenas distan unas millas de Palestina, una Palestina fuertemente helenizada ${ }^{8}$. Uno no puede imaginarse al traductor judío del Cantar ajeno al influjo de esos centros culturales.

Ahora bien, los textos antiguos decaen o incluso desaparecen no sólo por factores externos como puede ser la censura, civil o religiosa, dentro de la comunidad encargada de transmitirlos. Algunos, sin que sepamos muy bien la causa, fueron escondidos en vasijas de barro, como los documentos de Qumrán o Nag Hammadi descubiertos hace cincuenta años. Otros textos, sin llegar a compartir este destino, puede decirse que también sucumbieron bajo los escombros de siglos de interpretación alegórica en las comunidades que los trasmitieron. Uno de éstos es el texto bíblico del Cantar de los Cantares. Por eso cuando el lector se topa con una nueva traducción del original se puede hablar con razón de un redescubrimiento del Cantar. Y no es casual que el profesor Garbini termine su excelente monografía con la aguda observación de que tan sólo hace unos decenios ha descubierto la Iglesia que en el Cantar se habla de amor ${ }^{9}$.

Mi estudio se va a centrar en un momento concreto de la historia literaria del Cantar, la lectura helenística, es decir, cómo fue la primera traducción del Cantar más bello y qué reacción produciría en sus lectores. La primera traducción del Cantar al griego fue también la primera interpretación de estos poemas, puesto que cada traducción es el registro de una lectura real. Y tuvo que tener unos lectores; en efecto, nadie escribe una obra sin pensar en los posibles lectores reales o supuestos. Y si se trata, como es el caso, de una traducción, los destinatarios adquieren un protagonismo aún mayor: a ellos deben llegar los traductores trasvasando unos poemas de amor desde la lengua origen, en este caso una lengua semítica, el hebreo, hasta la lengua término, en este caso indoeuropea, el griego, con todo lo que este intento conlleva de audacia cultural.

\footnotetext{
${ }^{8}$ M. Hengel, Judentum und Hellenismus, Tubinga 19732, págs. 108-191.

9 «E se solo da qualche decennio la chiesa ha scoperto che nel Cantico si parla di amore», cf. G. Garbini, Cantico dei Cantici, Brescia 1992, pág. 252.
} 
En cuanto primera traducción del Cantar tiene además el interés de ser la primera interpretación conocida del libro, primera y única interpretación literal que constatamos dentro del judaísmo. Pues no hay que olvidar que a finales del siglo I E. c., cuando pasa a formar parte del canon de las Escrituras, ya se ha impuesto la lectura alegórica según la cual Dios es el esposo, la comunidad de Israel la esposa y en la trama del Cantar se codifican todas las peripecias del pueblo de Israel con su dios Yahweh. Buen testimonio de ello será la traducción aramea o Targum del Cantar, interpretación midrásica a medio camino entre el texto bíblico y el midrás Šir haširim $R a b b \hat{a}^{10}$.

La traducción de la Septuaginta por el contrario se mantiene pegada a la matriz original del Cantar. Su literalismo es tal que hay que insertar al traductor en aquella corriente o tradición del siglo primero de la Era común que optó por ajustar al máximo la traducción de la Septuaginta al texto hebreo entonces en curso, y que desembocaría con el andar del tiempo en la traducción palabra por palabra de Aquila ". Ciertamente este tipo de traducción literal verbum de verbo no deja resquicio para la interpretación alegórica. De todas formas, como advierte el nieto de Ben Sira, sabemos que las palabras no tienen la misma fuerza dichas en el original que

${ }^{10}$ Cf. D. Barthélemy, "Comment le Cantique des Cantiques est-il devenu canonique?», en A. CAQUOT - S. LÉGASSE - M. TARDIEU (eds.), Mélanges bibliques et orientaux en l'honneur de M. Mathias Delcor, Neukirchen - Vluyn 1985, 13-22; y para el Targum, cf. F. MANNs, "Le Targum du Cantique des Cantiques. Introduction et traduction", Liber Annuus Studium Biblicum Franciscanum 41 (1991) 223-302. H. Fisch lamenta que no podamos discernir, por mucho que nos remontemos, trazas de una interpretación «literal» temprana del Cantar tal como ocurre con Homero antes de que los estoicos lo legitimasen filosóficamente con su interpretación alegórica, cf. "Song of Solomon: The Allegorical Imperative", cap. 6 en H. FISCH, Poetry with a Purpose, Bloomington - Indianápolis 1990, 80-104, 97. Pues bien, pace Fisch, esta interpretación está perfectamente reflejada en la traducción griega del Cantar.

"M. HARL, "On the Greek Version of the Song of Songs", BJGS 5 (1989) 11-12. Observa con acierto la profesora Harl que apenas se conservan lecturas de Teodoción en el Cantar griego mientras que son frecuentes las de Áquila y Símaco; esto sería un indicio de que o bien la Septuaginta del Cantar pertenece al grupo кá́re-Teodoción o se confundió con él. En todo caso este literalismo de la traducción excluye todo rastro de interpretación alegórica: «Taking the text as a whole, the Greek version is neutral with regard to an allegorical interpretation" (ibid. pág. 11); ver también $\mathrm{M}$. HARL, «La version LXX du Cantique des Cantiques et le groupe Kaige-Theodotion», Textus 18 (1996) 101-120. 
cuando se traducen a otra lengua ${ }^{12}$ y puesto que los dos sistemas lingüísticos, el del hebreo y el del griego, no se solapan, persisten una serie de opciones en las que el traductor, por literal que quiera ser, ejerce de intérprete. Pues bien, es en esos pasajes que traicionan al traductor literal donde es posible sorprenderlo.

Trataré por fin de extraer algunas conclusiones sobre la persona del traductor en el ámbito del judaísmo de su época ${ }^{13}$ y sobre la recepción de esta traducción o los posibles lectores de esta nueva creación literaria. Nuestro interés se centrará en el lector implícito, codificado en el texto mismo de la traducción, y en el contexto cultural de los lectores de entonces así como en las reacciones que en ellos suscitaría una obra como ésta, no en los lectores reales de épocas posteriores como la nuestra. Para ello contamos con una obra literaria, en este caso una traducción, con sus convenciones formales y sus estrategias de comunicación, en el caso del Cantar una especie de rompecabezas que el lector tiene que resolver si quiere acceder a un sentido o a una plena comprensión ${ }^{14}$. En el caso de una traducción literal al griego como la del Cantar se acentúa todavía más el protagonismo del lector, pues la obra se convierte a menudo en un enigma que hay que descifrar con la ayuda de ciertas claves que dependen en buena medida de la competencia del lector, sus registros lingüísticos, históricos y culturales necesarios para la actualización del texto.

\footnotetext{
12 Prólogo a la traducción griega del Eclesiástico 21-22: «Que no tienen la misma fuerza las expresiones cuando se dicen en hebreo que cuando se traducen a otra

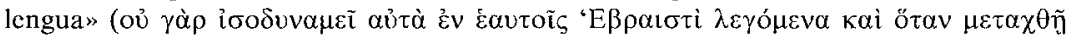

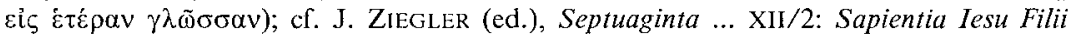
Sirach, Gotinga 1965, pág. 125.

${ }^{13}$ La traducción griega del Cantar debe situarse, en mi opinión, en torno al cambio de era. Si aceptamos la datación del Cantar original que presenta Garbini en torno al año 70 a. E. c., tan sólo mediaría medio siglo entre la composición original y la traducción. Yo me inclino, sin embargo, por el siglo III-II a. E. c. como fecha más probable para la redacción final del texto hebreo, es decir en pleno período helenístico. La fecha de la traducción antes indicada encajaría bien dentro de lo que hoy sabemos de la tradición de revisiones de la Septuaginta para adaptarla al texto hebreo en curso a lo largo del siglo I E. c. e incluso antes; cf. O. MUNNICH, "Contribution à l'étude de la première révision de la Septante", ANRW II, 20.1, Berlín - Nueva York 1987, 190-220.

14 M. DAvies, "Reader-Response Criticism" en R. J. Coggins - J. L. Houlden (eds.), A Dictionary of Biblical Interpretation, Londres 1990, 578-580, 578; y B. C. LATEGAN, "Reader-Response Theory», en D. N. FRIEDMAN (ed.), The Anchor Bible Dictionary, vol. 5, Nueva York 1992, 625-629.
} 
Pero para el especialista de la Septuaginta que va buscando la originalidad de la traducción en cuanto obra literaria en sí misma y las diferencias que van apareciendo aquí y allá frente al texto original hebreo, la lectura del Cantar griego no puede ser más frustrante ${ }^{15}$. En efecto, el traductor se ciñe al texto hebreo en tal medida que buscar los añadidos y omisiones propios de otros libros bíblicos es tarea vana. Uno llega a preguntarse si un lector de lengua griega era capaz de comprender algunos pasajes sin conocimientos del hebreo, porque en algunos casos para salir de apuros no basta con la tolerancia semántica del contexto. Bien es verdad que en textos como los del Cantar no se trata tanto de comprender cuanto de sugerir sentidos que cada uno ha de recomponer a partir de sus propios registros y experiencias. Las diferencias entre el Cantar hebreo y griego son más sutiles y a ellas nos vamos a volver ahora.

La diferencia de mayor envergadura entre el texto griego del Cantar y el hebreo ${ }^{16}$ se encuentra en el conjuro que repite el amado (2,7 y 3,5): "por las gacelas o por las ciervas del campo". La Septuaginta traduce siempre en estos pasajes 'por las fuerzas y por

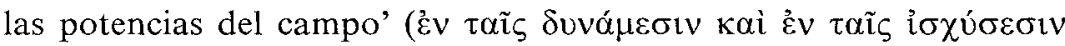

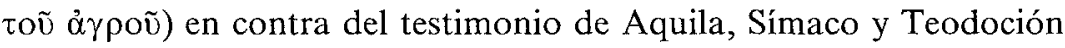

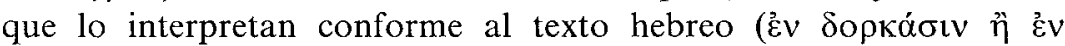

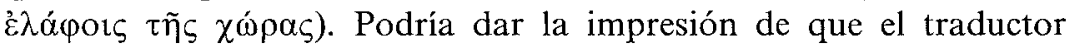
griego nos traslada a un tema de la religiosidad helenística, la teoría de las fuerzas del cosmos que conectan todas las partes del mundo

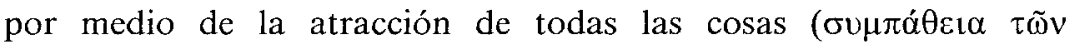
$\delta \lambda \omega \nu)^{17}$. Y sin embargo la explicación más convincente es que el traductor leyó de forma diferente el mismo o parecido texto he-

\footnotetext{
15 El especialista hará bien en volverse a Isaias (cf. I. L. SEELIGManN, The Septuagint Version of Isaiah, Leiden 1948), a los Salmos (cf. J. ScHAPER, Eschatology in the Greek Psalter, Tubinga 1995), a Job (cf. N. FERnÁndez Marcos, "The Septuagint Version of the Book of Job», en W. A. M. BEuken (ed.), The Book of Job, Lovaina 1994, 251-266) o al libro de los Proverbios (cf. G. GERLEMAN, Studies in the Septuagint. III: Proverbs, Lund 1956), si quiere de verdad encontrar la interpretatio graeca de los diversos traductores.

16 Para el texto hebreo sigo la edición de F. Horst en la Biblia Hebraica Stuttgartensia, Stuttgart 1975, y para el griego la edición de A. Rahlfs (ed.), Septuaginta, Stuttgart 1935, aunque he consultado también la edición de R. HolmES - J.P PARSONS (eds.), Vetus Testamentum Graecum, III, Oxford 1823.

17 M. P. NILSON, Geschichte der griechischen Religion. Zweiter Band: Die hellenistische und römische Zeit, Munich 1961², págs. 534-539.
} 


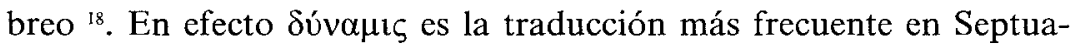
ginta para צבא (recordemos la expresión אúpı Yahweh Șěba'ôt) y también en Aquila; y en el caso de i $\sigma \chi u ́ s$ el traductor leyó probablemente en del texto masorético, puesto que nִ es traducido por ỉ $\sigma$ úc tanto en Septuaginta como en Aquila. Ambas letras $n / \mathcal{N}$ son fáciles de confundir por el dictado interno.

Otras ligeras diferencias de interpretación se encuentran en 1,3-4 donde el griego traduce y puntúa: "por eso te aman las muchachas, tiran de ti; al olor de tus perfumes corremos tras de ti'. En 2,4 en lugar del hebreo "y su enseña sobre mí es amor" la Septuaginta

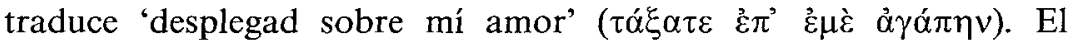
traductor leyó con toda probabilidad דִ דגל imperativo de la raíz ('desplegar banderas o pabellones') en lugar del sustantivo hebreo

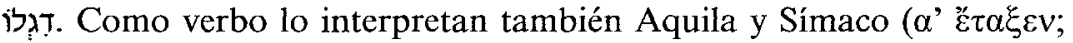
$\sigma^{\prime} \dot{\varepsilon} \pi(\sigma \omega \rho \varepsilon v 0 \alpha \tau \varepsilon)$. En 4,9 hay una diferencia en el pronombre personal: singular en hebreo, plural en la traducción griega, fácilmente explicable por la confusión paleográfica $I />$ en la escritura

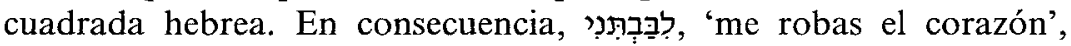

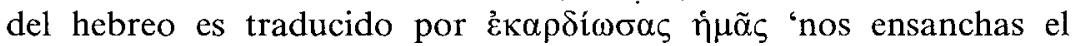
corazón'. Hay que advertir que esta variante del griego está atestiguada en un manuscrito hebreo ${ }^{19}$. Símaco en cambio lo entendió,

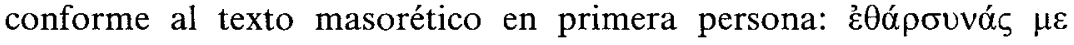
'me enardeces, das valor'.

En 6,7 el hebreo repite la descripción de la amada de 4,3, «como trozos de granado son tus sienes entre el velo", pero omitiendo los dos primeros esticos «como cinta de grana son tus labios, qué hermosa es tu boca». Pues bien, la Septuaginta vuelve a repetir tal cual en este pasaje los cuatro esticos de 4,3. Dado el literalismo del traductor es muy posible que encontrase estos dos esticos repetidos

\footnotetext{
${ }^{18}$ En la interpretación de este verso hay que tener en cuenta la práctica antigua de sustituir en un juramento el elemento sagrado por el nombre de un animal, planta u objeto. Mediante este eufemismo o circunlocución se evita el pronunciar el nombre de la divinidad; cf. E. Fernández Tejero, El cantar más bello, Madrid 1994, pág. 77; y A. Robert - R. Tournay - A. Feuillet, Le Cantique des Cantiques, Paris 1966, pág. 108: "Ajoutons que le poète peut évoquer dans cette formule conjuratoire le

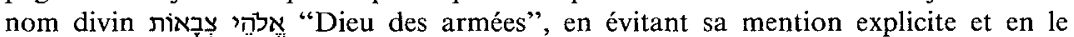

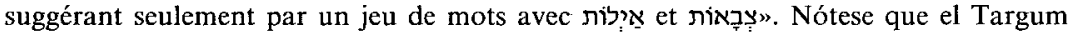
al Cantar traduce el juramento 'por el Señor de los ejércitos y por los poderosos de la tierra de Israel'; cf. F. MANNS, art. cit., pág. 271.

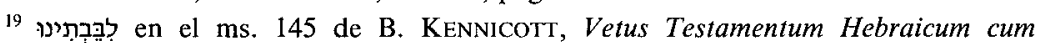
variis lectionibus, $\mathrm{II}$, Oxford 1780.
} 
en su Vorlage hebrea, o completara la descripción de la amada a partir del pasaje paralelo de 4,3 .

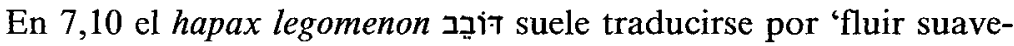
mente', y el verso, "tu paladar es como vino ... que se vierte sobre los labios de los que duermen». En cambio el griego traduce íavoú-

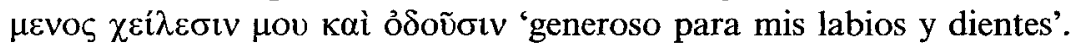
Vuelve a mediar una confusión $I /$, en la lectura de la última

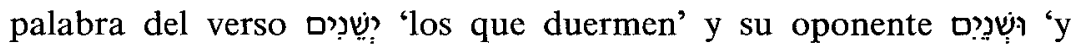
dientes'. Yo prefiero mantener la lectura íavoú $\mu \varepsilon v o \varsigma$ de los manuscritos en lugar de la corrección que algunos proponen, iк $\alpha$ vó $\mu \varepsilon v o \zeta$, puesto que el verbo íóv $\omega$, aunque más acorde con el sentido incierto de דבב 'moverse', no suele construirse con dativo. El traductor griego realizaría una típica «traducción de perplejidad» ante una palabra cuyo significado real desconocía.

Por fin, en 8,10 en lugar del hebreo "entonces seré a sus ojos como quien ha encontrado la paz», la Septuaginta lee y traduce 'yo era a sus ojos...'. Teniendo en cuenta la escrupulosidad con que el traductor vierte las partículas hebreas, hay que concluir que esta discrepancia se basa en una lectura diferente del texto base hebreo en el que el traductor leería אָנִ en lugar del dxָ del texto masorético.

En resumen, por estos ejemplos se puede concluir que para todas las diferencias frente al hebreo detectadas en la traducción hay una explicación textual, una posible confusión de letras en el texto consonántico o distinta vocalización de un texto hebreo muy similar al texto masorético que conservamos. Y, al contrario, no he detectado ningún ejemplo de traducción claramente interpretativa o alusión al universo lingüístico y cultural del helenismo. Sorprende en especial la ausencia de motivos mitológicos en torno a Eros y Afrodita, tan iterativos en la poesía erótica helenística, por no hablar de la ausencia de la métrica propia de la lírica griega y de los rasgos dialectales eolios y dorios que suelen aparecer en este tipo de composiciones.

Sin embargo, la selección de ciertas palabras y el poder evocador de las mismas permite descubrir algunos guiños del traductor hacia la literatura griega, por ejemplo, cuando en 2,5 y $5,8 \mathrm{~d}$ traduce el 'enferma de amor' del hebreo por 'herida de amor' (ó $\tau \imath \tau \varepsilon \tau \rho \omega \mu \varepsilon ́ v \eta$ $\dot{\alpha} \gamma \alpha \dot{\alpha} \pi\rceil \zeta \hat{\varepsilon} \gamma(\dot{)})^{20}$. Garbini piensa que detrás de esta lectura griega está un texto hebreo distinto, un verbo חלל nלה nez del verbo

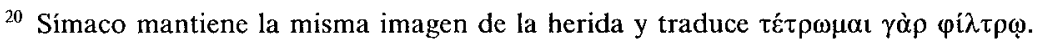


texto masorético ${ }^{21}$. Creo, sin embargo, que el traductor se ha dejado arrastrar por la metáfora helenística de las flechas de Eros, enormemente difundida en la poesía y el arte, y la conocida expresión

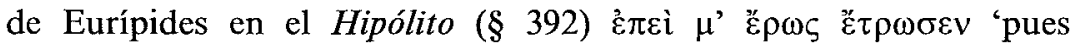
Amor me ha herido' ${ }^{22}$.

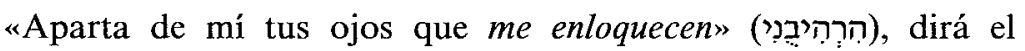
amado en 6,5 siguiendo el texto hebreo. En cambio el griego traduce 'aparta de mi tus ojos que me excitan' (literalmente 'me dan alas',

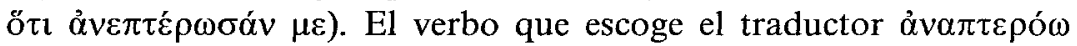
'salir alas' en modo alguno está sugerido por el texto masorético, 'confundir, turbar'. Garbini piensa que el traductor leyó un verbo distinto רחב 'ensanchar, hacerse grande' que en hif'îl significa también 'excitar'. De hecho hay un manuscrito, el 231 de Kenni-

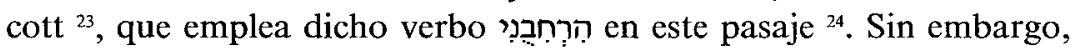
a mi entender, el término griego está escogido por asociación con el mito del amor que describe Platón en el Fedro (249d y 255c). Platón emplea ese mismo verbo y conocemos el poder evocador que tienen en la literatura helenística siertos términos usados por los clásicos ${ }^{25}$.

Por fin, en 8,5 el hebro dice "¿Quién es la que sube del desierto?»

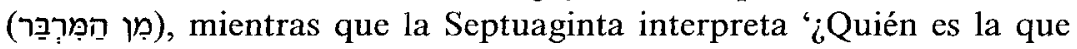
sube toda de blanco?' ( $\lambda \varepsilon \lambda \varepsilon v \kappa \alpha v \theta \imath \sigma \mu \varepsilon ́ v \eta)$. Si en 3,6, donde se repite el mismo sintagma, el traductor griego vierte correctamente 'del desierto', es de suponer que aquí se encontró con un texto hebreo diferente. Garbini así lo entiende y restaura מִלְבְּנון 'del Líbano', leído por la Septuaginta como לְבָָָ, 'blanca' ${ }^{26}$. Pienso que detrás de la lectura griega puede estar la metáfora de la luna llena, en hebreo «la blanca» לָדָנָ (cf. 6,10), el disco de la luna llena que, en el libro

${ }^{21}$ G. Garbini, Op. cit., pág. 45.

22 G. G. A Murray (ed.), Euripidis fabulae, Oxford 1966, vol. I.

23 Cf. nota 19.

24 G. Garbini, Op. cit., pág. 72.

25 Cf. la traducción de L. Gil, Banquete, Fedón, Fedro, Madrid 1969, del último pasaje citado (Fedro, 255c): 'La corriente de la belleza llega de nuevo al bello mancebo a través de los ojos, el conducto por donde es natural que se encamine hasta el alma; y excitándola vivifica los orificios de las alas y los impulsa a criar plumas, llenando a su vez de amor el alma del amado'. El amor homosexual, está

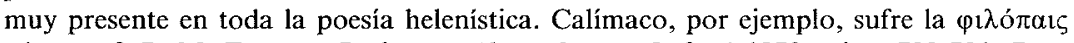
vóбoc; cf. P. M. Fraser, Ptolemaic Alexandria, I, Oxford 1972, págs. 790-791. Para la interpretación del pasaje en los Padres griegos cf. M. HARL, La langue de Japhet, París 1992, pág. 138.

${ }^{26}$ G. Garbini, Op. cit, pág. 117. 
XI del Asno de oro de Apuleyo, alzándose desde el mar, prefigura la epifanía de Isis ${ }^{27}$.

Hemos comentado el poder evocador de ciertas palabras de la traducción griega del Cantar. Habría que añadir que el clímax poético se mantiene en la traducción por medio de recursos estilísticos semejantes a los del original, como son la repetición de las mismas palabras e imágenes, las plantas, los aromas y perfumes, las piedras preciosas, los colores... Pese a la ausencia de los ritmos de la poesía helenística, puede advertirse cómo en algunos casos se mantienen, y en otros tal vez mejoran, las figuras de lenguaje del original. He aquí algunos ejemplos de aliteración en griego que

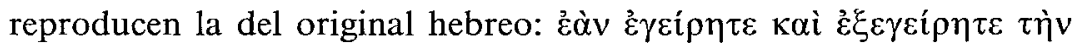

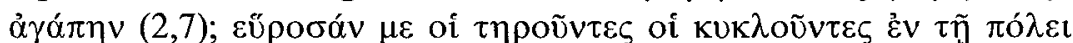

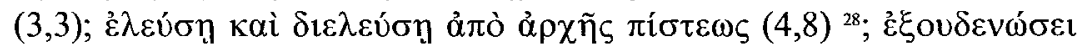

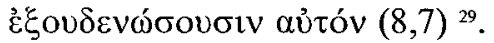

Una aproximación a la traducción griega del Cantar desde la perspectiva de la recepción de la obra por parte de los lectores del siglo I E. c. puede resultar interesante. Me inclino a pensar en un público exclusivamente judío como destinatario de la obra. En efecto, la ausencia de los metros propios de la poesía lírica griega tenía que resultar extraña a oídos grecorromanos. Si a ello añadimos el literalismo a ultranza que produce pasajes difícilmente inteligibles dentro del sistema griego se confirma mi hipótesis de un público judío como principal receptor de la traducción ${ }^{30}$.

A ello hay que añadir las numerosas transliteraciones de palabras difíciles como en 4,4 «como torre de David es tu cuello, edificada

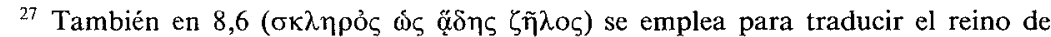
los muertos, en hebreo bịi, un término técnico griego conocido desde Homero, $\not \not \delta \eta \zeta$, , cuyo campo semántico no coincide con el del hebreo, pero, a pesar de todo, es el mejor equivalente dentro del sistema griego, a menos de decidirse por una trasliteración del término hebreo, como acostumbra a hacer el traductor en otros pasajes del Cantar.

28 En hebreo «de la cumbre de Amaná». La Septuaginta traduce el topónimo hebreo y modifica el sentido del verso. En este caso falta la aliteración en el original hebreo.

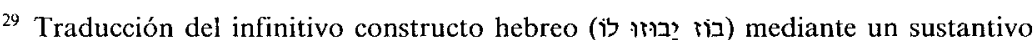
de la misma raíz, mientras que Símaco recurre al participio del mismo verbo como

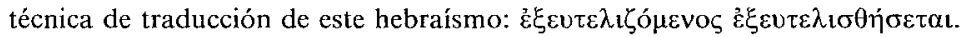

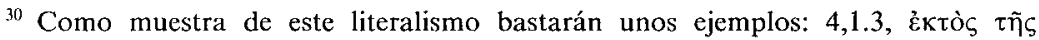

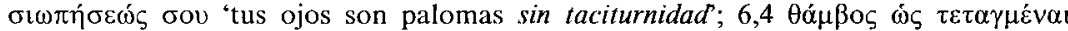


( $\varepsilon i \varsigma) ~ \theta \alpha \lambda \pi \omega \theta \theta$; mirra y $\alpha \lambda \omega \theta$ en $4,14{ }^{31}$; en 5,11 , la cabeza del amado es «de oro y $\varphi \alpha \zeta$ " ${ }^{32}$, que suele traducirse por "oro puro, oro acrisolado'.

Estos resultados obtenidos a partir del análisis lingüístico se confirman indirectamente, puesto que no conocemos ninguna cita del Cantar en los autores grecolatinos de la antigüedad. Es más, a pesar de estar gran parte de la Biblia traducida al griego desde el siglo III a. E. c., apenas se conocen citas de ella en autores que no estén vinculados con la tradición judeo-cristiana ${ }^{33}$.

No sólo el literalismo de la traducción constituye un obstáculo para el lector helenístico, sino que el texto griego del Cantar mantiene intactas las referencias constantes a la geografía local del área de Palestina, claves inconfundibles de la historia de Israel y alusiones veladas por medio de palabras-reclamo a diversos pasajes del universo bíblico, en especial el de los orígenes, tal como se describen en los primeros capítulos del Génesis.

En efecto, las alusiones a la geografía de Palestina y al pasado de Israel forman parte de las principales constelaciones de metáforas e imágenes del Cantar: las muchachas de Jerusalén $(1,5 ; 2,7 ; 3,5 ; 5,8$ y 8,4), las tiendas de Quedar y las tiendas de pieles de Salomón $(1,5)$; los carros del Faraón $(1,9)$ y las viñas de En Guedi $(1,14)$; las montañas de Betel $(2,9)$; el lecho y la litera de Salomón, hecha de madera del Líbano $(3,7.9)$; la mención de Galaad $(4,1)$ y la torre de David $(4,4)$; la cresta del Senir y del Hermón $(4,8)$ y los montes,

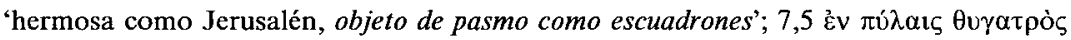
$\pi \circ \lambda \lambda \tilde{\omega} v$ 'tus ojos como estanques en Hesbón, a las puertas de la hija de muchos', vacío de sentido en el que ha desembocado por traducir el topónimo hebreo

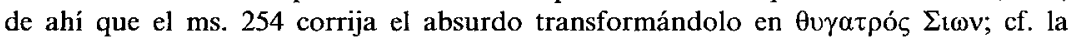
edición de R. Holmes - J. PARsons citada en nota 16.

31 Corregido en $\alpha \lambda$ on en algunos minúsculos; cf. la edición de R. Holmes - J. PARSONS citada en nota 16.

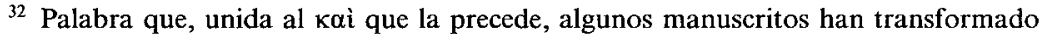

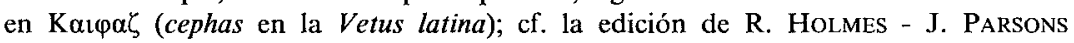
citada en nota 16, ad locum.

33 G. RinALdi, Biblia Gentium, Roma 1989. La primera cita, que corresponde a Gén 1,3, se encuentra en el autor anónimo del tratado De Sublimitate 9,9 del siglo I E. c. atribuido al Pseudo-Longino. Y la mayoría de los testimonios de escritores grecorromanos son juicios polémicos o negativos sobre la Escritura (G. RiNALDI, Biblia, pág. 121). "It is, however, undeniable that for the pagan reader, whether philosopher or man of average learning, the biblical texts were found unacceptable", observa Rinaldi (pág. 109). 
bosques, torres y ríos del Líbano (4 passim y 7,5); los carros de Aminadab $(6,12)$; la Sulamita $(7,1)$; los estanques del Hesbón, Damasco y el Carmelo (7,5-6); la viña de Salomón en Baal Hamón $(8,11)$.

Si nos fijamos en el vocabulario, la omnipresencia del huerto ( $\kappa \tilde{\eta} \pi \circ \varsigma)$ y la fuente $(\pi \eta \gamma \eta ́)$ como metáforas de la amada $(4,12-13)$ y

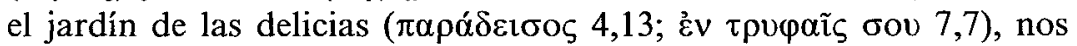
remite al jardín del Edén ${ }^{34}$ en una nueva búsqueda del paraíso perdido en el que todas las plantas, aromas y piedras preciosas se convierten en una metáfora del amor. El amor emerge como única respuesta a la muerte $(8,6)$, como única posibilidad de trascender la realidad y recuperar el paraíso perdido ${ }^{35}$.

De ahí que por encima de los paralelos del Cantar hebreo con Teócrito y la cultura alejandrina de su autor, tan brillantemente defendida por Garbini ${ }^{36}$, el lector de la traducción griega no pueda dar un paso sin esta serie de referencias intertextuales que le ofrecen los otros libros de la Biblia y en particular los primeros capítulos del Génesis. Pues todo el libro no es sino una sinfonía lírica de las primeras palabras que pronuncia el hombre en la Biblia: "Ésta sí que es hueso de mis huesos y carne de mi carne»" ${ }^{37}$.

La traducción griega del Cantar, al igual que el original, estremece por el vigor con que transmite la experiencia amorosa. Es la mejor canción a la vida. Pienso que junto a él la mayoría de los idilios de Teócrito, los epigramas alejandrinos y las anacreónticas

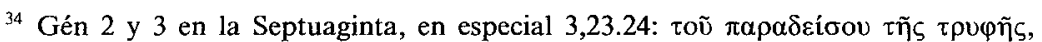
en J. W. Wevers (ed.), Septuaginta ... I: Genesis, Gotinga 1974, págs. 94-95.

${ }^{35}$ Sorprende en el Cantar la ausencia de motivos típicos del epigrama helenístico: la muerte de la amada, el rechazo, el amor imposible, el amor efimero, etc. En el Cantar casi todo es paradisíaco y lo envuelve un aura de Edén al que no acceden ni los temores, ni el rechazo, ni el entorno social, ni la dura realidad. El $\kappa \tilde{n} \pi$ $\kappa \varepsilon \kappa \lambda \varepsilon\llcorner\sigma \mu \varepsilon ́ v o \zeta ~(4,12)$ u hortus conclusus del Cantar, el locus amoenus de nuestros clásicos del Siglo de oro, son evocaciones de este gan 'eden o paraíso de los orígenes, como horizonte último siempre añorado cada vez que un encuentro real con el amor nos hace soñar imposibles.

${ }^{36}$ G. Garbini, Op. cit., págs. 299-303, donde describe otros temas de la poesía alejandrina presentes en el Cantar y que se encuentran, sobre todo, en los epigramas de Meleagro y Filodemo de Gadara.

${ }^{37}$ Cf. Gén 2,23. Se ha dicho al comentar este verso que Dios se retira cuando el hombre y la mujer se unen, poniendo en relación la ausencia de Dios en este pasaje con la ausencia de Dios en el Cantar (cf. la dudosa mención de la divinidad en Cantar 8,6); cf. A. Brenner, A Feminist Companion to the Songs of Songs, Sheffield 1993, pág. 101. 
suenan a bellas ficciones literarias. Así que se puede razonablemente concluir que los judíos helenizados serían los principales destinatarios de esta traducción.

Mas intentar a partir del texto deducir el grupo social de los lectores o la personalidad del traductor mismo en el ámbito del judaísmo del siglo I E. c. no es tarea fácil. Tanto el lenguaje original del Cantar como el de la traducción griega es escurridizo. Hay muchos pasajes en los que el sentido es incierto. En otros, es sugerente y evocador, pero queda abierto a distintas interpretaciones. Estos vacíos de sentido los ha de llenar el lector según sus competencias y resonancias culturales. Incierta permanece tantas veces la identidad del que habla que muchos pasajes son difíciles de entender en un contexto real. De ahí que algunos autores hablen de que en los poemas se alterna entre sueño y realidad. El amado tan pronto aparece de pastor como adornado de los atributos regios y comparado a Salomón.

En todo caso el lector implítico del Cantar griego se funde con el traductor que se perfila como un judío culto, refinado, con conocimiento de la lengua griega y parte de la literatura helenística, y con un dominio de la literatura bíblica, traducida ya en su mayor parte al griego. Todos estos condicionantes están suponiendo un judío de clase acomodada y no necesariamente de un medio lujoso o cortesano, teniendo en cuenta que los personajes del Cantar permanecen en el aire, sin concretar, como en un fanal de éxtasis, y que los lujos de los aromas y de las piedras preciosas son ante todo una metáfora del amor.

La traducción griega del Cantar es anterior a la obra de Flavio Josefo, pero probablemente contemporánea de Filón de Alejandría, de las escuelas de Šammai y de Hiil-lel y de los hombres de Qumrán, la asamblea de congregados de la Nueva Alianza, asentados en las orillas del mar Muerto. Josefo aceptó, al parecer, la interpretación literal del Cantar ${ }^{38}$. Filón y otros autores judeo-helenísticos se inclinaron por la interpretación alegórica de la Biblia, aunque no tengamos testimonios concretos de su exégesis del Cantar.

\footnotetext{
${ }^{38}$ En toda la obra de Josefo no se menciona el Cantar. El interés de Josefo es la historia y, en consecuencia, tan sólo al hablar de Salomón (Antigüedades, VIII, 44)

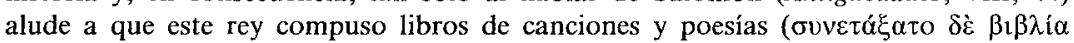

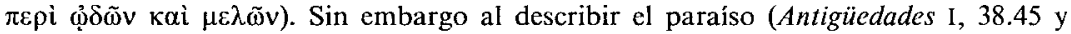

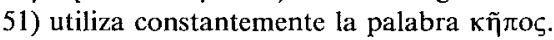


Hoy sabemos además que el Cantar hebreo se leía en Qumrán, pues en las cuevas 4 y 6 han aparecido varios fragmentos aún no publicados ${ }^{39}$. Al parecer estos fragmentos de Qumrán abrevian intencionadamente el texto del Cantar. Lo que está claro es que la Septuaginta sigue el texto masorético al traducir y no el abreviado de Qumrán ${ }^{40}$.

Sabemos también que al encontrarse con el helenismo los judíos de la diáspora, y los de Palestina, ensayaron prácticamente todos los géneros de la literatura griega: escribieron novelas o cuentos didácticos de enamorados como José y Asenet y novelas de corte como Ester, Judit, o Susana; ensayaron la tragedia sobre temas judíos como el del Éxodo (Ezequiel el trágico) o la épica como Filón el poeta y Teódoto; cultivaron la literatura sapiencial, el género de testamentos y de oráculos; desarrollaron la literatura apocalíptica, compusieron himnos y poesía litúrgica.

Pero fuera del Cantar no encontramos otros ejemplos de literatura lírica erótica, ni en Qumrán (donde han aparecido tratados de brontología, horóscopos, textos de magia, escritos sapienciales como el de la mujer demoníaca y seductora de 4Q184), ni en la extensa literatura pseudoepigráfica ${ }^{41}$. En el Cantar la literatura hebrea alcanzó la cumbre de la lírica y se mantuvo con la traducción al griego. Fue algo insólito y sin epígonos. Es más, en el ámbito del judaísmo del siglo I el libro del Cantar - estoy de acuerdo con Garbini- supuso una propuesta revolucionaria ${ }^{42}$ y como tal se

${ }^{39}$ E. UlRICH, «An Index of the Passages in the Biblical Manuscripts From the Judean Desert (Part 2: Isaiah-Chronicles)", DJD 2 (1995) 86-107, 105. Ver también E. Tov, «Three Manuscripts (Abbreviated Texts?) of Canticles from Qumran Cave 4», JSJ 46 (1995) 88-111; ÍDEM, «Excerpted and Abbreviated Biblical Texts from Qumran", $R Q 64$ (1995) 581-600; e ÍDEM, "Letters of the Cryptic A Script and Paleo-Hebrew Letters Used as Scribal Marks in Some Qumran Scrolls», DJD 2 (1995) 330-339.

40 4QCant ${ }^{\mathrm{a}}$ omite Cant 4,7-6,11 y 4QCant ${ }^{\mathrm{b}}$ omite Cant 3,6-8 y 4,4-7. Se trata, pues, de dos versiones abreviadas o extractos del texto del Cantar, no comentarios o paráfrasis de dicho texto. ¿Se trataría de una especie de ediciones de bolsillo con fines devocionales? En todo caso son el testimonio de un uso del Cantar distinto del de los círculos rabínicos y que no tiene inconveniente en editarlo abreviado y tal vez para uso personal. Cf. E. Tov, «Excerpted and Abbreviated", pág. 599: «This indicates that these texts come from a certain milieu, one which differed from the circles fostering the tradition of the writing of Scripture texts».

${ }^{41}$ M. Stone, Jewish Writings of the Second Temple Period. Apocrypha, Pseudepigrapha, Qumran Sectarian Writings, Philo, Josephus, Assen/Maastricht - Filadelfia 1984.

${ }^{42}$ G. GARBINI, Op. cit., pág. 320. 
mantuvo en su traducción al griego. Supone una exaltación del amor físico y del erotismo frente a las corrientes de misoginia y los ataques al sexo y a las relaciones extraconyugales de la literatura sapiencial que, a cambio, colma de elogios a la Sabiduría personificada en una mujer ${ }^{43}$. El autor y traductor griego del Cantar están polemizando sin mencionarlos con Proverbios 1-9 y el libro de Ben Sira, y es probable que Sabiduría 2,6-9 esté polemizando con el Cantar ${ }^{44}$. En el Cantar asistimos a la exaltación del amor humano y la fascinación de la mujer que se convierte en protagonista omnipresente sin que por ningún resquicio se perciba la menor sombra de conflicto social, familiar o religioso.

Este mismo frescor mantiene la traducción griega. La búsqueda de sentido llevará a los copistas posteriores a dotar a los poemas de estructura teatral o coral, señalando las entradas a los principales actores a la manera de la Comedia Nueva y la tragedia. Y así aparecieron en los principales unciales (los códices Alejandrino y

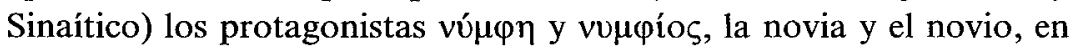
la escena del poema ${ }^{45}$.

En suma, volviendo al título de este trabajo, quiero concluir con una afirmación que tal vez parezca paradójica: existe una traducción griega del Cantar, pero no una lectura helenística o interpretatio graeca del mismo. Bajo una aparente helenización formal de pequeña escala, lo que tenemos - y esto es lo importante- es la primera y única interpretación literal en lengua griega que los judíos hicieron del Cantar en el período helenístico-romano ${ }^{46}$.

${ }^{43}$ N. Fernández Marcos, «Exégesis e ideología en el judaísmo del siglo I: héroes, heroínas y mujeres», Sefarad 53 (1993) 273-288.

44 Así lo ve G. Garbini, Op. cit., pág. 340.

45 A. Rahlfs (ed.), Septuaginta, págs. 270-271. En manuscritos de la Vetus Latina veremos ya transformados estos personajes, novio y novia de los manuscritos griegos, en actores concretos de un drama convertido ya en alegoría: sinagoga, iglesia, Cristo, los herejes, María Magdalena; cf. D. DE BRUYNE, «Les anciennes versions latines du Cantique des Cantiques", RevBén 38 (1926) 97-122.

46 Tampoco aparecen claros los motivos de la traducción al griego del Cantar. No debió de influir la práctica de su lectura en la liturgia sinagogal, pues la costumbre de leer la Ley de Moisés estaba bien arraigada en el siglo I E. c. tanto en Israel como en la Diáspora, pero la lectura de los otros rollos, en concreto del Cantar en la fiesta de Pascua, sólo se admitió en la liturgia en época post-talmúdica, cf. TB-Sôfĕrîm 14,3 y CH. Perrot, «The Reading of the Bible in the Ancient Synagogue», en M. J. Mulder (ed.), Mikra. Text, Translation, Reading and Interpretation of the Hebrew Bible in Ancient Judaism and Early Christianity, Assen/Maastricht - Filadelfia 1988, 
La traducción griega del Cantar ensancha el conocimiento que tenemos del judaísmo en torno al cambio de era por lo que desvela del traductor y por los lectores que implícitamente está suponiendo esta obra, de la misma manera que los documentos del mar Muerto han agrandado la imagen de este judaísmo desvelando un pluralismo de grupos sociológicos y religiosos que se consideraba impensable hace medio siglo. Traducción y original del Cantar transmiten experiencias humanas de todos los tiempos y no específicamente religiosas. Y lo sorprendente es que fuera incorporado a la colección de libros sagrados como único en su género de poesía lírica erótica al lado de la literatura sapiencial, didáctica, litúrgica, profética o apocalíptica.

Los historiadores del judaísmo en el período del Segundo Templo tendrán que hacer un hueco para este grupo sociológico que revela el entorno del Cantar. Tanto autor como traductor difícilmente podían sospechar que, andando el tiempo, esta colección de poemas eróticos iba a encontrar un lugar en las Escrituras, aunque fuera a costa de domesticar su frescura original pasándola por el tamiz de la interpretación alegórica. Al recuperar su sentido literal y genuino nos devuelve a nosotros, lectores modernos, las mismas alas que en su día hizo nacer en los lectores judeohelenísticos.

137-160, 147 y 149. No obstante, las escuelas de Hillel y de Šammai coinciden en que el Cantar impurifica, es decir, que ya en el siglo I E. c. es considerado inspirado o canónico. $\mathrm{Y}$ a fínales del siglo I E. c., cuando en torno al sínodo de Jamnia ya consta la interpretación alegórica del Cantar, era uno de los 22 libros canónicos citados por Josefo (Contra Apión I, 40) y posiblemente uno de los 24 libros canónicos que menciona el libro IV de Esdras XIV 44-46; cf. R. T. BECKWITH, "Formation of the Hebrew Bible", en M. J. MuLder (ed.), Mikra, 39-86, en especial 69-71. 


\section{RESUMEN}

El artículo analiza la versión griega del Cantar de los Cantares bajo dos puntos de mira: en cuanto traducción del hebreo y en contraste con la poesía erótica helenística. El análisis pone de relieve el literalismo de la traducción. En efecto, la mayoría de las discrepancias frente al texto masorético admite una explicación textual, mientras que no se encuentra en ellas rastro de interpretación alegórica. La importancia de esta versión reside en que es el primer testimonio de una interpretación literal del Cantar de los Cantares. El autor da un paso más e indaga en el trasfondo sociocultural del traductor y en el tipo de lectores implícitos a los que va dirigida la traducción griega, y concluye que, a la luz de este texto, se ensancha y enriquece nuestro conocimiento del judaísmo en la época del Segundo Templo.

\section{SUMMARY}

This article examines the Septuagint version of the Song of Songs under two perspectives: as a translation from the Hebrew and in contrast to the Hellenistic erotic poetry. The analysis emphasizes the literalism of the translation: the major part of the deviations from the Masoretic Text admit a textual explanation, while no trace of allegorical interpretation is found. The importance of the version consists of being the first witness of a literal interpretation of the Song of Songs. The author inquires further into the socio-cultural background of the translator and the kind of implicit readers that the Greek version is intended to, and he concludes that, in the light of that text, our knowledge of Judaism in the Second Temple period is enlarged and highly enriched. 